\title{
Membincang Keadilan Tuhan (Teodise) dalam Bencana Tsunami di Aceh
}

\author{
Haidar Bagir
}

Earthquake that happens at Aceh Provinve currently appears question mark: what will God do? Why The Beneficent and the Merciful God creates disaster and tsunami? Instead, this disaster causes many people died as the victims. Those issues contain the books of theology, when human knows religion and Greek philosophy. Why earthquake happens at Aceh? Certainly some people regard as waming or punishment especially for Acehnese on one hand and on the other hand they need the new generation birth bevause of the deadlock of their problem solution that without ending. This article traces the problem solution from philosophical point of view.

Kata kunci: teodise, bencana, Aceh, filsafat

$\mathrm{D}$ i antara segala kepiluan, kegalauan, dan kepanikan melakukan apa saja yang mungkin menghadapi katastrofi dahsyat, sebagaimana gempa dan tsunami di Aceh baru-baru ini, biasanya selalu muncul pertanyaan besar: apa mau Tuhan dengan semua ini? la bisa melintas otomatis dan tidak disengaja, bisa juga merupakan kebutuhan filosofis yang sedikit atau banyak lebih terelaborasi, tapi ia sulit ditekan-dan sesungguhnya memang tak bisa ditekankhususnya bagi pikiran-pikiran yang memuji rasionalisme. Maka, melewati kejadian besar seperti ini, chaos biasanya diikuti dengan semacam aktivitas sour searching, yang bisa membawa kita kepada iman yang lebih kuat, atau justru krisis teologis yang mengguncang.

Pertanyaan yang menyembul tanpa bisa ditahan-tahan itu adalah: Kenapa Tuhan yang Mahapengasih dan Penyayang, yang Mahakuasa (yang kekuasaannya tak terbatas) membiarkan-kalau tak malah menciptakan-keburukan semacam gempa dan tsunami yang menimbulkan korban jiwa, benda, dan penderitaan mahadahsyat seperti ini? Apa mau Dia? Jangan-jangan Tuhan tak sepenyayang dan sepengasih yang kita kira? Bahkan sesungguhnya dia mahapemarah? Di mana keadilan Tuhan kalau Tuhan seperti yang dikenal orang-orang beragama memang ada?

Inilah sesungguhnya isu yang telah mengisi buku teologi, nyaris sejak kali pertama agama dikenal manusia. Atau, setidaknya, sejak orang mengenal filsafat. Dari zaman pemikir Yunani "pelbegu" seperti Plato, bahkan jauh sebelumnya, hingga pemikir Yahudi, Kristen, Islam, atau dari kelompok pemikir mana pun, masalah ini telah menjadi salah satu isu penting dalam filsafat dan teologi. Nyaris tak satu pun buku terkait dengan teologi yang tak menjadikan isu ini bagian pembahasannya. Namun, kapan saja katastrofi dahsyat terjadi, isu ini kembali mencuat sebab betapapun banyak penjelasan diupayakan, tak bisa semua orang dipuaskan, bahkan tak ada pikiran filosofis yang bisa sepenuhnya dipuaskan. 
Tentu saja ada alternatif penjelasan yang mungkin bisa diterima meski tak sepenuhnya filosofis, melainkan eksplikatif.

Dalam disiplin pemikiran, filsafat memang tak mulai dari asumsi yang sudah terlebih dahulu diyakini kebenarannya dan berangkat dari situ menawarkan penjelasan logis, sebagaimana yang dilakukan teologi (dialektis). Di antara penjelasan teologis yang biasa ditawarkan adalah bahwa bencana seperti ini sesungguhnya peringatan dan hukuman Tuhan bagi kebaikan-harapan akan peningkatan kualitas-manusia sendiri, yakni manusia yang masih hidup. Sementara itu, yang menjadi korban dipercayai akan diperlakukan dengan adii oleh Tuhan di alam lain. Apalagi, sebagai bagian dari paket penjelasan ini, bukankah penilaian akan keadilan Tuhan tak bisa berhenti hanya pada kehidupan dunia ini? Bukankah perhitungan baru selesai di akhirat nanti? Masih dalam rangka penjelasan teologis seperti ini, ada yang bahkan berusaha menjelaskan katastrofi-terkadang sambil mendukungnya dengan bukti kesejarahan-sebagai pendahulu bagi sebuah kelahiran baru yang lebih menjanjikan.

Kenapa di Aceh? Tentu ada yang menganggapnya sebagai peringatan atau hukuman terutama untuk rakyat Aceh sendiri, tapi ada pula yang merasa hal ini terjadi justru karena Aceh membutuhkan sebuah kelahiran baru setelah tampak. kebuntuan penyelesaian masalahnya yang berlarut-larut dan tanpa tanda-tanda penyelesaian.

Tulisan ini dibuat tanpa pretensi memberi solusi tuntas dan memuaskan terhadap pertanyaan yang usianya setua peradaban manusia ini. Kalaupun ada kontribusinya, hal itu terletak pada upayanya memaparkan__atau, malah, hanya meringkaskan__solusi yang pernah ditawarkan terhadap persoalan int. Dan, bukannya teologis, pendekatan yang dipakai bersifat nyaris sepenuhnya filosofis. Jika setelah membaca tulisan ini orang paham persoalannya sama sekali tak sederhanadan, karena itu, tak gegabah menarik kesimpulan atas persoalan terdalam hakikat kehidupan manusia di bumi ini,maka saya menganggap tujuan penulisan ini sudah tercapai.

Dirumuskan secara logis-diskursif, ihwal keadilan Tuhan akan mengambil bentuk silogisme sebagai berikut :

1. Tuhan ada

2. Tuhan baik

3. Tuhan mahakuasa

4. Tuhan mahatahu

5. Dunia mengandung kejahatan atau keburukan

Berdasar premis-premis di atas, orang merasa dapat menyimpulkan secara logis adanya inkonsistensi. Bagaimana mungkin Tuhan yang baik serta mahakuasa dan mahatahu menciptakan atau membiarkan kejahatan atau keburukan di dunia?

Menurut John L Mackie' , solusi yang ditawarkan terhadap apa yang dilihat sebagai inkonsistensi logis di atas bisa dibagi dalam dua kategori utama: kategori yang menolak setidak-tidaknya salah satu premis, dan kategori kedua yang mempertahankan semua premis. Mackie menganggap kategori pertama mencakup solusi yang "mencukupi" dan kategori kedua mencakup solusi yang "rancu".

\section{Kategori pertama}

Contoh penting kategori pertama adalah argumen bahwa kekuasaan Tuhan tidak absolut. Misalnya, Tuhan atau Demiurgos (Sang Tukang Pencipta Alam Semesta) yang dinyatakan Plato dalam Timaeus tidak dapat menjalankan kekuasaan tanpa batas 
sebab di dunia ada dua asas: materi dan forma (bentuk, sifat yang menjadikan materi bersifat tertentu yang menjadikannya suatu benda tertentu). Demiurgos tak mampu menjadikan materi bentuk apa saja yang la maui; la sama sekali tak dapat memengaruhi bentuk (forma). Maka, Tuhannya Plato tak dapat disalahkan akibat tidak menjadikan kursi, meja, singa, dan seterusnya sebagai benda sempurna sebab materi yang jadi sumber penciptaan dan ketidaksempurnaan semua benda merintangi kehendak dan tindakan Tuhan. Ini tak berarti mengatakan Demiurgos bebas dari tanggung jawab atau kesalahan atas segala kejahatan yang telah atau akan terjadi di dunia, karena Dia sesungguhnya dapat mencegah beberapa tindakan yang menyebabkan kejahatan dan Dia memiliki kuasa melakukan atau tidak melakukan hal itu. Bagaimanapun, penolakan Plato terhadap kekuasaan absolut Demiurgos menghapuskan masalah kejahatan sebagai sebuah kontradiksi karena kehadiran setidak-tidaknya suatu kejahatan, yakni ketaksempurnaan benda material, adalah sesuatu yang tidak dapat dikontrol oleh Demiurgos yang baik.

Pandangan kedua, yang konsisten menegaskan Tuhan itu baik dan kejahatan itu ada, berasal dari kaum Manikhean. (Mungkin juga dari agama Hindu). Dalam pandangan ini, Tuhan yang diidentikkan dengan kebaikan tidak memiliki kuasa selain atas benda-benda yang baik. Benda-benda yang jahat diciptakan oleh "okrium" Tuhan yang lain: Tuhan kejahatan. Di sini masalah kejahatan tidak muncul karena entah kita membicarakan Tuhan kebaikan entah Tuhan kejahatan, kontradiksi mudah dihindari. Tuhan kebaikan tidak memiliki kuasa selain atas benda-benda baik; karenanya kejahatan muncul bukan karena kehendak Tuhan. Sedang Tuhan kejahatan, la bukan hanya Tuhan yang terbatas kuasanya (karena memiliki kuasa hanya atas benda yang jahat), la pun memang bukan Tuhan kebaikan. Sebenamya la memang memiliki pembawaan sifat jahat. PenciptaanNya atas kejahatan tidak hanya tidak bertentangan dengan SifatNya, melainkan justru konsekuensi sifatNya.

Tipe solusi kedua dimasukkan ke dalam kategori pertama karena bukannya menghapuskan satu atau lebih sifat Tuhan, ia justru menghapuskan kejahatan. Salah satu solusi yang masuk ke dalam kelompok ini menganggap kejahatan sebagai ilusi, sedang solusi lain menganggapnya sebagai ketiadaan kebaikan. Beberapa sekte Hindu seperti Madyamika, misalnya, percaya bahwa seluruh dunia fenomena dengan segala sesuatu yang muncul di dalamnyabenda yang hidup atau mati, baik atau jahathanyalah sebuah ilusi. Dunia ini dimanifestasikan pada kita sebagai real karena pemahaman pikiran kita dibatasi sebagai akibat dari keterpisahannya dengan pikiran absolut atau makrokosmos. Jika kita dapat menghindari diri kita dari keterbatasari pikiran dan melihat benda sebagaimana tampak pada pikiran makrokosmos, semua yang kita alami tentang benda-benda fenomena, termasuk penderitaan dan kebahagiaan, kejahatan dan kebaikan akan menghilang. Yang tersisa adalah visi tentang keseluruhan, yang tidak mencerminkan pembedaan di antara benda, nilai, atau segala hal lain. Apakah pandangan semacam itu masuk akal merupakan persoalan di luar cakupan tulisan ini. Yang menjadi perhatian kita adalah fakta bahwa ajaran dasarnya tak mengalami inkonsistensi yang ditimbulkan akibat adanya (konsep tentang) kejahatan-setidaktidaknya ketika ajaran ini diuraikan dalam bentuknya yang eksplisit-karena sesungguhnya kejahatan tak memiliki eksistensi real di dunia. 
Mengenai pandangan yang mereduksi kejahatan menjadi tiadanya kebaikan, seperti juga pandangan yang menganggap kejahatan sebagai ilusi, ia mencoba memecahkan masalah dengan menghapuskan kejahatan sebagai sebuah realitas positif. Contohnya, ketunarunguan, kebutaan, sakit, kebodohan dan kelemahan adalah ketiadaan pendengaran, penglihatan, kesehatan, pengetahuan, dan kemampuan. Karena merupakan ketiadaan, maka kejahatan atau keburukan tak membutuhkan sumber atau pencipta karena penciptaan hanya berhubungan dengan keberadaan.

Persoalannya, kenapa alam tidak diciptakan dengan cara sedemikian sehingga keberadaan bisa menggantikan ketiadaan? Jawaban terhadap persoalan ini bisa diperoleh dengan memfokuskan perhatian pada karakteristik dunia natural. Aksi dan reaksi yang resiprokal dari maujud material, perubahan, penggantian, konflik, dan interierensi adalah karakteristik esensial dunia material. Jika karakteristik ini tidak ada, maka dunia material juga tidak ada. Dengan kata lain, sistem kausal spesifik dunia material adalah suatu sistem esensial yang dibutuhkan oleh sifat dasar maujudmaujud material. Oleh karena itu, dunia material haruslah entah terwujud dengan sistem ini entah ia tak akan terwujud sama sekali. Di sisi lain kemunculan sebuah fenomena baru bergantung pada kemusnahan (atau pemusnahan) fenomena yang lama (yang ada sebelumnya). Demikian pula, ketahanan hidup suatu maujud hidup tergantung kepada pengonsumsian dan, karena itu, pemusnahanmaujud-maujud hidup lainnya. Misalnya, ketahanan hidup manusia bergantung pada pengonsumsian hasil tanaman atau hewan tertentu. Argumentasi terakhir ini antara lain diajukan dalam (filsafat) Hikmah yang bersumber dari aliran Akbarian, aliran yang didasarkan pada pemikiran Syaikh al-Akbar Ibn 'Arabi.

\section{Kategori kedua}

Dalam kategori kedua, yang di dalamnya semua premis dipertahankan, kita menemukan empat tipe solusi yang didasarkan pada empat penafsiran mengenai kejahatan.

Pertama, kejahatan adalah efek (akibat) yang diperlukan dari kebaikan. Beberapa kebaikan tidak mungkin ada tanpa suatu kejahatan yang secara absolut berasal darinya. Api, misalnya, adalah baik-untuk memasak, menghangatkan, dan banyak tujuan kebaikan lain-tetapi ia tak dapat ada sebagai api tanpa pada saat yang sama memiliki kuasa membakar yang berharga dalam keadaan tertentu. Maka, kejahatan adalah akibat tak terhindarkan dari adanya beberapa kebaikan; menghapuskannya berarti pada saat yang sama menghapuskan sebabnya, yang pada kenyataannya merupakan kebaikan-yang nilai positifnya melebihi nilai negatif kejahatan. Bertentangan dengan solusi yang diurajkan dalam kategori pertama, tipe solusi ini, bersama dengan tiga solusi berikutnya, tidak menolak komponen dasar ajaran teistik. Semua sifat Tuhan dipertahankan dan tetap dianggap absolut; kejahatan juga diakui sebagai fakta di dunia. Yang diupayakan adalah pembenaran terhadap Tuhan yang menyebabkan atau mengizinkan kejahatan.

Kedua, kejahatan adalah sarana yang diperlukan untuk kebaikan. Menurut pandangan ini, kejahatan selalu terjadi agar dapat membawa sesuatu yang lebih baik daripada yang telah ada. Menampar anak kecil, misainya, adalah kejahatan, tetapi ini berguna mendisiplinkan anak. Gempa bumi, banjir, kebakaran, dan bencana lain adalah juga kejahatan, tetapi semua itu memiliki 
pengaruh yang baik, seperti menurunkan populasi, mengajarkan pada mereka yang masih hidup bagaimana menghadapi penderitaan dan kesulitan dan mungkin menimbulkan peristiwa yang baik dalam hubungannya dengan alam semesta secara keseluruhan-kebaikan yang menurut keterbatasan pandangan kita tidak (atau mungkin tidak dapat) kita pahami sebagai kebaikan. Dengan pendakuan semacam itu, tipe solusi ini disebut sebagai "pembelaan bagi kebaikan yang lebih tinggi".

Neison Pike ${ }^{2}$ adalah salah satu pendukung terkenal abad ke-30 terhadap "pembelaan atas kebaikan yang lebih tinggi". Pike menyatakan solusi ini tidak berasal "dari pendakuan bahwa sebuah wujud yang sangat baik akan mencegah penderitaan, jika ia dapat". Pike berargumen sesuatu bisa baik meski pada saat yang sama menimbulkan kejahatan, tetapi sesuatu itu harus "memiliki alasan moral yang kuat" untuk melakukan demikian:

Misalnya, seorang ayah yang memberi anaknya sesendok obat pahit tidak boleh disalahkan karena ia melakukan demikian agar dapat mengobati anaknya dari penyakit. Meminum obat adalah perigalaman tak menyenangkan bagi seorang anak dan, karena itu, merupakan suatu jenis keburukan, tetapi hal ini merupakan sarana untuk kebaikan yang lebih tinggi: untuk memulihkan kesehatan anak. Maka, seorang ayah, meski bertanggung jawab memberi obat kepada anaknya, terbebas dari kesalahan yang menimbulkan kejahatan: ia memiliki "alasan moral yang kuat". Pike berpendapat bahwa argumen yang sama dapat diterapkan pada Tuhan. Tuhan yang memiliki pengetahuan tentang penderitaan yang dialami oleh makhluk tertentu ketika ditimpa penyakit, penderitaan, dan seterusnya-dan memiliki kuasa mencegah penderitaan semacam itu-masih tetap tidak mencegahnya. Namun, Tuhan tidak bisa dituduh jahat karena alasan melakukan itu secara moral adalah kuat: Tuhan yang menyebabkan atau tidak mencegah kejahatan memiliki tujuan menghasilkan kebaikan yang lebih tinggi untuk individu yang ditimpa kejahatan atau untuk alam semesta secara keseluruhan. Dengan kata lain, jika Tuhan mencegah menghasilkan beberapa kejahatan, sama saja Dia mencegah menghasilkan beberapa kebaikan yang lebih tinggi.

Namun, bagi sebagian orang, analogi antara manusia dan Tuhan ini dapat menimbulkan pertanyaan lebih lanjut. Memang sulit bagi seorang ayah, dengan keterbatasan manusiawinya, mengobati anaknya dari penyakit tanpa memberinya obat yang pahit. Namun, Tuhan dianggap memiliki kekuasaan yang absolut dan, karena itu, pasti dapat menghasilkan kebaikan tanpa harus memakai sarana kejahatan. (Dengan kata lain, untuk dapat diterima, harus dicatat bahwa pembelaan ini dan pembelaan sebelumnya secara implisit sebenarnya membatasi kekuasaan Tuhan, meski keduanya mendakukan mempertahankan semua premis dasar yang dicatat di awal tulisan ini). Perlu saya sampaikan di sini, keberatan ini sesungguhnya mengandung inkonsistensi. Yang diupayakan adalah penjelasan (manusiawi yang bersifat) rasional terhadap isu keadilan Tuhan. Dengan kata lain, sejalan dengan hukum-hukum yang berlaku di dalam domain kehidupan manusia, kaidah yang harus dipakai menyampaikan keberatan terhadapnya harus menggunakan kaidah yang sama. Melompat kepada ukuran yang tak rasional secara manusiawi, semisal mengharap Tuhan memberi obat yang tidak pahit, bisa dianggap sebagai contoh kerancuan semacam ini. 
Ketiga, kejahatan menambah keragaman di dunia dan karena itu membuat dunia kita menjadj dunia terbaik dari duniadunia yang mungkin (diciptakan). Menurut pandangan ini, kejahatan dibenarkan bukan karena pendakuan bahwa ja tak terhindarkan agar dapat memunculkan beberapa kebaikan yang penting, tetapi karena pendakuan bahwa ia memiliki nilai positifnya sendiri. Jika kejahatan dihilangkan, maka kita akan mendapati kurangnya keragaman (sebagaimana kata Leibniz) atau kurangnya kemungkinan yang bisa diwujudkan (sebagaimana kata Ibn Sina) dibandingkan dengan yang seharusnya-dengan kata lain, kebaikan yang bisa kurang daripada yang seharusnya atau dibandingkan dengan yang telah kita miliki. Idenya, semakin banyak keragaman dan semakin terpenuhinya kemungkinan adalah lebih baik, dengan syarat bahwa keragaman dan kemungkinan yang terpenuhi itu diintegrasikan dengan kesatuan dan keteraturan. Hadirnya kejahatan memberi dunia kita jumlah keragaman yang lebih besar dibandingkan dengan jika tidak ada; karenanya, dunia ini akan lebih baik bila ada kejahatan dan akan lebih baik dari dunia apa pun yang kurang memiliki campuran antara kebaikan dan kejahatan.

Keempat, kejahatan bukanlah tindakan Tuhan atau produk dari tindakan Tuhan, melainkan produk dari kebebasan kehendak manusia. Ini adalah pembelaan yang dipergunakan membebaskan Tuhan dari tanggung jawab atas kejahatan moral, bukan kejahatan metafisis. Jika manusialah yang, karena kebebasan mereka, menimbulkan kejahatan moral, maka ditegaskan bahwa hadirnya kejahatan semacam itu tidaklah bertentangan dengan kebaikan Tuhan. Namun, harus dinyatakan pula bahwa merujukkan kejahatan moral kepada kebebasan kehendak manusia tidaklah dengan sendirinya menawarkan solusi sempurna atas masalah kejahatan. Di samping fakta bahwa solusi yang terpisah harus disediakan untuk kejahatan fisik dan metafisik, harus diuraikan pula dua hal penting berkenaan dengan kebebasan manusia: alasan Tuhan menyebabkan atau mengizinkan adanya kebebasan kehendak manusia, yang mengetahui bahwa dengan adanya kebebasan kehendak itu, kemungkinan kejahatan juga ada; dan apakah Tuhan dapat membuat orang berbuat benar setiap saat meski dengan fakta bahwa mereka itu bebas. Pembelaan yang memberikan jawaban kepada dua hal tersebut sekarang biasa disebut dengan "pembelaan atas kebebasan kehendak".

"Pembelaan atas kebebasan kehendak" mendakukan bahwa sebuah dunia dengan makhluk yang memiliki kuasa untuk apa yang baik dan apa yang buruk secara bebas adalah lebih baik daripada sebuah dunia yang di dalamnya makhluk hanya melakukan apa yang benar, tetapi tidak secara bebas. Ini adalah jawaban terhadap. poin pertama yang disinggung di atas, tetapi ia hanya salah satu tesis dari "pembelaan atas kebebasan kehendak", dan bukan yang paling fundamental. Garis argumen yang diambil merespons poin kedua adalah garis argumen yang berada di pusat perdebatan hangat dalam pemikiran kontemporer. Menurut argumen ini, Tuhan tak dapat memberi kebebasan kepada makhluk dan pada saat yang sama menjamin bahwa makhluk ini akan selalu melakukan apa yang benar secara bebas.

Tesis kedua ini membutuhkan tesis pertama agar pembelaan itu bisa sempuma. Jika Tuhan tidak dapat memberi kebebasan pada orang dan pada saat yang sama membuat mereka selalu dan dengan bebas menjalankan perbuatan yang benar, 
mengapa Tuhan tidak menahan kebebasan mereka agar mereka dapat menghindari keberadaan atau kemungkinan kejahatan moral? Pembela atas kebebasan kehendak siap menyatakan bahwa kebẹbasan adalah lebih baik daripada tanpa-kebebasan, dan bahwa sebuah dunia dengan kebebasan semacam itu adalah lebih diinginkan dan lebih baik daripada sebuah dunia tanpa kebebasan. Dengan kata lain, "pembelaan atas kebaikan yang lebih tinggi" adalah langkah pertama yang harus diambil di dalam "pembelaan atas kebebasan kehendak". Ketika langkah itu diambil, maka pembela atas kebebasan kehendak harus menegaskan ketidaksesuaian antara premis "Orang adalah bebas" dan premis "Tuhan dapat menentukan orang selalu berbuat benar secara bebas".

Ketidaksesuaiari semacam itu dipertahankan dengan kuat oleh orang-orang seperti John Hick dan Alvin Plantinga. Namun, ketidaksesuaian tersebut, sebagai inti dari "pembelaan atas kebebasan kehendak", juga memiliki lawan yang tangguh, seperti John Mackie, Antony Flew, dan Dewey Hoitenga.

Maka, pembela kebebasan kehendak berusaha mernecahkan persoalan kejahatan dengan mengingkari kemahakuasaan Tuhan. Setelah memberi manusia kebebasan kehendak, Tuhan tidak dapat membimbing perbuatan mereka; jika Tuhan melakukan ini, mereka tidak akan bebas. Dengan kata lain, kebebasan manusia memberi batasan pada kekuasaan Tuhan.

Kesimpulannya, solusi utama terhadap masalah kejahatan dapat cibagi menjadi dua tipe:
Kategori pertama, tipe solusi yang menolak setidak-tidaknya salah satu premis yang dicantumkan pada awal tulisan ini. Contoh-contoh dari tipe solusi ini adalah (a) solusi yang menghapuskan satu atau lebih sifat Tuhan, seperti sifat kuasa; dan (b) solusi yang menghapuskan konsep tentang kejahatan.

Kategorj kedua, tipe solusi yang tidak secara eksplisit menolak semua premis. Contoh-contoh dari tipe ini adalah bahwa (a) kejahatan pasti berasal dari kebaikan; (b) kebaikan membutuhkan kejahatan sebagai sarananya; (c) kejahatan menambah keragaman atau pemenuhan berbagai kemungkinan di dunia, dan ini adalah sesuatu yang baik; dan (d) kejahatan moral disebabkan oleh kebebasan kehendak manusia, bukan Tuhan.

Diskusi, malah perdebatan sengit, mengenaj masalah ini pasti tak akan berhenti di sini. Hampir dipastikan ia akan tetap tinggal sebagai persoalan kontroversial, setelah puluhan abad dalam keadaan demikian. Barangkali Tuhan, bagi yarig percaya kepada keberadaan dan keadilannya, memang menyisakan isu ini sebagai satu di antara berbagai misterinya dan, dengan demikian, membiarkannya tetap tinggal sebagai misteri. Sebuah misteri, yang kalaupun bisa dipecahkan, harus diselesaikan dengan cara lain. Barangkali lewat sebuah pengalaman, sebuah perjumpaan, sebuah pencerahan spiritual, ketimbang penjelasan rasional, apalagi filosofis. 